\title{
OSMIČKOVÉ VÝROČIA V KONTEXTE SLOVENSKEJ LITERATÚRY
}

\author{
MARTA GERMUŠKOVÁ
}

GERMUŠKOVÁ, Marta: Years of "Eights" in the Context of Slovak Literature, 2019, Vol. 1, Issue 1, pp. 12 - 21. DOI: 10.17846/CEV.2019.01.1.12-21.

ABSTRACT: The author focuses on topics related to historical events that took place in the eighth years in a common state - in the first Czechoslovakia, later in the Czechoslovak Socialist Republic and in the Czechoslovakia, but especially in Slovakia. The author of the paper tries to outline the "reflection" of key political and historical events in selected poems and prose of Slovak writers. Linking history, politics and literature critically reflects the author, seeking through the interpretation of selected literary texts to indicate the attitudes of writers to break events in our history and to evaluate their artistic and human contribution.

KEYWORDS: Slovak Literature. Eighty Anniversaries. History. Politics. Interpretation.

V dejinách nášho novodobého národa sú osmičkové roky až zarážajúco signifikantné, pretože počas nich sa uskutočňovali kardinálne zmeny, prípadne politické prevraty, ktoré mali raz pozitívnejšie, inokedy však aj tragické následky pre život ludí a fungovanie štátu vo všetkých oblastiach. Počiatky našich pokusov o získanie jazykovej i politickej samostatnosti predstavuje slovenská revolučná jar v roku 1848, na čele ktorej stál politický líder L. Štúr a nevídaná aktivita členov jeho "družiny“. V meruôsmych rokoch sa inšpirovali myšlienkami a silou európskych revolúcií aj Slováci. Bolo to ich prvé revolučné vystúpenie vo feudálnom Uhorsku. Ludovít Štúr sa stal prvým významným slovenským politikom a otvoril etapu moderných slovenských dejín, čo vystihuje aj jeho esej Starý a nový vek Slovákov. Uvedená časová dvojfázovost je tu jasne vymedzená; starý vek Slovákov trval od vzniku Vel'kej Moravy do roku 1800 a nový vek začal na prahu 19. storočia. Ludovít Štúr využil vo svojej stimulatívnej eseji vel’a metaforiky, štylisticky mimoriadne účinný a hlavne svojský jazyk, aby poukázal na to, aké bolo spolužitie Slovákov s pohanskými Madarmi na začiatku a čo všetko pre nich urobili Slováci v priebehu istého času. Išlo o to, že ich priviedli k viere, preukázali schopnosť žit’ s nimi v mieri a pokoji, ukázali im svoju pracovitost' na poliach, takže Madari sa mohli od Slovákov mnohému naučit', nehovoriac už o tom, ako toto spolužitie obohatilo ich lexiku. V časti eseje s názvom Nový vek Slovákov Štúr písal o tom, že práve tento čas priniesol Slovákom obrovský útlak a podmanenie si Slovákov pyšnými Madarmi. Nový vek Slovákov ako prvý odštartoval práve L. Štúr svojím jazykovým bojom, teda bojom proti násilnej mad’arizácii a mad’arskému šovinizmu. Všetci Slováci, ktorí participovali na jazykovom boji v Uhorsku, boli totiž považovaní za zradcov a buričov. V tejto súvislosti treba pripomenút historicky dôležité vystúpenie slovenského národného lídra L'udovíta Štúra ako poslanca na Uhorskom sneme, kde 15. januára 1847 žiadal zabezpečenie vzdelávania detí v materinskom jazyku. Okrem toho Štúr načrtol situáciu neslobodného ludu, pre ktorého žiadal slobodu, bohoslužby v materinskej reči, hovoril o vlasti a potrebe vzdelanosti, ktorá povznesie náš národ. Zaujímavé sú aj dobové časopisecké materiály, ktoré svedčia o tom, ako útočili uhorské časopisy proti Štúrovi ako vodcovi v tomto boji, no nikdy mu neuverejnili jeho obranné články. Jednoznačné zameranie mad’arskej vlády proti nemad’arským národom vychádzalo z myšlienky, že všetky národy a národíky sa musia zrieknut svojho materinského jazyka, lebo na madarskej zemi sa živia a madarský chlieb prijímajú.

Zaujímavým stimulom pre celý slovanský svet bol dátum 2. 6. 1848, kedy sa v Prahe konal Slovanský kongres. Jeho cielom bolo spájat slovanský svet a slovanské sily, pretože slovanské národy patrili k zotročovaným národom. Slovanská otázka a slovanský fenomén v danom 
období vzbudzovali záujem aj v iných krajinách Európy, vo Francúzsku zvlášt', čomu sa venovala aj francúzska tlač. Štúr vystúpil 3. júna 1848 v Prahe na zhromaždení Slovanov s velkým zápalom a s najväčším úspechom, pričom jeho úderná rétorika bola oceňovaná obrovskými aplauzmi a nekonečným jasaním. Medziiným tam zazneli aj tieto jeho historicky dôležité, odvážne a radikálne slová: „Už dlho sme slúžili za hračku diabolskej politiky, ktorá nás plánovite vzájomne oddelovala a ustavične rozoštvávala, aby sme tak vlastnou vinou upadali. My však nechceme d'alej slúžit takému satanášstvu! Dozreli sme, poznali sme svoje práva a chceme ich mužne bránit'. To však dosiahneme iba spojenou silou. Preto sme sa tu zišli dohovorit' o tom, aby nabudúce Česi konali za Slovákov a Chorvátov, Chorváti za Čechov a Slovákov a Slováci za obojich. A ked'sa takto spojíme, takto upevníme, potom nám nikto neodolá - a našich nepriatelov pochytí strach a hrôza“ (Danilák 1997, 86).

V slovenskej literatúre sa „zrkadlilo“ toto historické obdobie najmä v básňach Janka Krála, Jána Bottu, Sama Chalupku a iných. Boli to zvyčajne básnické agitky, ktoré vyzývali Slovákov do boja proti zotročovatelom. Išlo o apelatívny typ revolučnej poézie. Dôkazom revolučného naladenia i nádeje na zmenu čias (motív svitania) bola Králova báseň Krajinská pieseň z marca 1848. Jeho apel na zjednotenie Slovákov, potrebu ich boja za slobodu a proti katom, má v sebe silnú „dávku“ persuazívnosti a viery v Božiu pomoc.

Ďalším historickým medzníkom pre Slovákov bol vznik prvej Československej republiky 28. októbra 1918. Prvá ČSR bola nielen vytúženou métou Čechov a Slovákov, ale aj tažko vybojovanou realitou, na ktorej participovala slovenská i česká politická špička. Po dlhých desatročiach obrovského úsilia najvyšších predstavitel’ov obidvoch národov však došlo - po mnohých peripetiách - k vzniku unitárneho štátu, hoci Pittsburská dohoda z 30. 5. 1918 obsahovala v písomnej podobe pomlčku, teda názov štátu mal mat podobu Česko-Slovensko. Napriek počiatočným deklaráciám politikov a nádejam bežných ludí, došlo k výraznému deformovaniu toho, čo sa objavovalo $\mathrm{v}$ počiatočných sluboch a dohodách politikov. Historickú dohodu (v štáte Pensylvánia v Amerike) podpísali zástupcovia Slovenskej ligy v Amerike, Českého národného združenia a Zväzu českých katolíkov s budúcim československým prezidentom Tomášom G. Masarykom. Mala zabezpečit Slovákom rovnoprávne postavenie, slobodu, autonómnost', slovenčinu ako úradný jazyk, štátnu administratívu, súdnictvo a snem. Napriek mnohým negatívam, ktoré sa nakopili pri vzniku i d’alšom fungovaní prvej ČSR, nemožno neocenit fakt, že išlo - v prípade Slovenska - o značný posun vo všetkých oblastiach života Slovákov, teda v oblasti ekonomickej, politickej i kultúrnej, ktorá nás bude primárne zaujímat', pretože literárne umenie patrí do sféry kultúry a má nespornú ambíciu dvíhat národné povedomie a zároveň stimulovat reflexivitu človeka i dalšie aktivity práve v tomto „priestore“. V takom prelomovom čase, akým bolo konštituovanie prvej ČSR, získavala múzická literatúra významné postavenie v živote spoločnosti, pretože sa usilovala oduševňovat občanov nového štátu, ódizovat historicky prvý spoločný štát Čechov a Slovákov (P. O. Hviezdoslav) i jeho možnosti. Slovensko však velmi dlho a vo všetkých oblastiach života výrazne zaostávalo za Českom, bolo vnímané zo strany Čechov ako archaická krajina, agrárne orientovaná, a Slováci boli dlho vnímaní ako zaostalý národ. V umeleckej literatúre, v dejinách slovenskej literárnej vedy i vo sfére kultúry, preto treba pripomenút mená českých osobností pôsobiacich na Slovensku, akými boli Jaroslav Vlček, František Votruba, Ivan Gall, Karol Plicka, neskôr Peter Jilemnický a iní, ktorí významnou mierou participovali na „modelovaní “ kultúrnotvorných procesov a dvíhaní vzdelanostnej úrovne Slovákov (českí pedagógovia Pospísil, Volf a iní).

Z dôvodu historickej postupnosti a kontinuity sa budeme zameriavat iba na vybrané básnické texty, prípadne prozaické diela spisovatelov, ktoré boli múzickou reagenciou na významné politické medzníky v našich novodobých dejinách. Začneme vznikom prvej Československej republiky, pretože od nej sa odvíjali dalšie vývinové peripetie Čechov a Slovákov. Jednou z najvýznamnejších 
osobností prvej ČSR bol výnimočný slovenský spisovatel’ Pavol Országh Hviezdoslav. Hoci zomrel iba tri roky po jej vzniku, teda v roku 1921, bol očitým svedkom dejinného zlomu v roku 1918, eufórie našich národov i prvých „krôčikov“ nášho spoločného štátu. Dôkazom jeho vlastnej eufórie bola rozsiahla báseň s názvovou dedikáciou Mládeži československej. Hviezdoslav do nej zakomponoval „vodopád“ metafor, štylistických figúr i jazykových novotvarov (hviezdoslavizmov), ktorými chcel svojsky vyjadrit’ neopísatelnú radost' z uvedeného historického faktu. Hviezdoslav - najväčší slovenský bard - reagoval jeho vlastným múzickým spôsobom na novú historickú situáciu a označil ju za „jaro národa“, dokonca za „velejaro“, ktoré priniesla rozprávková Zlatovláska - Sloboda. Básnik bol vo svojich lyrických vyjadreniach nielen mimoriadne emotívny, ale i patetický; nešetril ódickou lexikou, no pri návratoch do minulosti pripomínal i tragickost' položenia vlastného národa (motívy poroby a neštastia, motív slabnúcej nádeje národa, jeho tažkých okov, príliš neskorého príchodu slobody - motív dlhej a tažkej púte Zlatovlásky Slobody k Slovákom), pričom aktuálny čas a výsledok zmeny nazval básnik „štastnou príhodou“. Vel'kého majstra pera však zaujímala hlavne budúcnost̉ národa, ktorá by podla neho mala mat’ nielen atribúty demokracie a slobody, ale Hviezdoslav apeloval predovšetkým na mládež, aby si vysúkala rukávy a oddane pracovala pre svoj národ. Žiadal od nej tvorivého ducha, vzletné myšlienky a „dejstvie“, teda činorodost', aktivitu, pracovitost', aby sa nová vlast’ stala pre národ „rajom krásy, pravdy a blaha“. Prirovnával radost’ oslobodeného národa k radosti na svadbe. Zároveň však vystríhal mládež pred takými nebezpečnými „diagnózami“ ako lieň, „rozpust“, pohodlnost’, sebalúbost', nestud, rúhavost’ a samospravodlivost'. Hviezdoslav ako človek - nachádzajúci sa vo finále svojho života - všetko uvedené pripomínal mládeži ako povinnost', pretože cítil rozhodujúcu dejinnú rolu mladých v porovnaní so „starešinou“, ktorá už nemala fyzických ani psychických síl na realizáciu nastupujúcich prevratných zmien. Použitý vekový kontrast je mimoriadne účinný, myšlienkovo stimulatívny, komparačný i esteticky pôsobivý. Hviezdoslavov básnický apel na mládež je funkčný, adresný a pragmatický. Výzvovost̉ je popri intímnom oslovovaní „drahá mládež spojená aj s akcentom lyrika na nasmerovanie jej úsilí. Topos štátu a topos domova sa zračí v uvedenej básni aj v pripomenutí geografických názvov - českých i slovenských hôr a riek (Šumava, Krkonoše, Dunaj, Tatry atd.).

V tejto súvislosti treba akcentovat fakt, že Hviezdoslav ako človek veril vo svetlú budúcnost spoločného štátu i slovenského národa a ako výnimočný a produktívny básnik vedel prostredníctvom funkčných a esteticky účinných prírodných metafor (akvatických, meteorologických a iných) i symbolov (Slnko ako dobro a plodonosnost', hviezdy ako predzvest' vysnívaného raja atd.) imaginovat obraz kvality budúceho života nášho národa ako vysnívaného raja. Znakom zrelej ludskej osobnosti je to, že má vízie a sny. A Hviezdoslav bol kreátorom budúcich vízií a snov národa, preto sa jeho báseň končí apoziopézou, aby aj potenciálny čitatel' mohol generovat vlastné sny a nádeje.

\author{
Hej - vy všetci bud'te zdravé, silné štepy \\ $v$ národnom tom ohrade, \\ s lístím, nádejou čo večnou šepoce, \\ hviezdami jak nebo jasnej za noci, \\ osýpané bez poškvrny kvetom: \\ zvestujúce, \\ zistujúce \\ šlachetné vždy, zlaté ovocie - \\ o raji že povest' rozletí sa svetom...
}


V roku 1919, teda na prvé výročie vzniku ČSR, napísal Hviezdoslav báseň Národe drahý. Jej názov je hodnotiacou i hodnotovou dedikáciou. Svoju neutíchajúcu radost̉ zo samostatného štátneho útvaru chcel P. O. Hviezdoslav vyjadrit tým, že on ako človek - pozorujúc obidva naše národy si uvedomoval, čo náš národ získal a čoho sa zbavil. Svojmu národu však kladie aj oprávnenú otázku, či si po roku spolužitia v spoločnom štáte uvedomuje a zároveň aj cíti, že so získaním práv a slobody si na svoje plecia pribral aj „bremä povinností“. Hviezdoslavovské motívy bratstva sú venované Čechom, pretože veril, že to bude osudové spojenie, evidentne cítil, že Slováci ako „zbedovaní tisícroční otroci“ majú Čechov v čom doháňat. Zároveň veril, že spolupráca obidvoch národov bude plodná. Vystríhal však Slovákov, aby neboli pre Čechov prítažou. P. O. Hviezdoslav ako človek i autentický lyrik sa koril pred Bohom, preto duchovná i etická dimenzia boli organickou súčastou jeho básnickej estetiky a poetiky. Zaujímala ho otázka viery a svedomia, príkaz mravnosti, primknutie človeka $\mathrm{k}$ princípom pravdy a spravodlivosti. Preto jeho básnický apel smeroval $\mathrm{k}$ tomu, aby sa slovenský národ pozitívnymi skutkami a rozosievaním dobra $\mathrm{v}$ „úcho krásy priodel“, pretože Slováci majú byt ohnivkami vo veliretazi dobra. Silná je aj jeho výzva, aby si Slováci udržali vieru, pretože je životodarná. Pestovat blízkost̉ s Čechmi bolo silnou túžbou Hviezdoslava. Pevne veril, že spriahnutím síl Slováci môžu len získat’ a metaforicky to vyjadril slovami: „I šibnete spolu šibnete vpred.../ V budúcnosti si zbudujete vlastnej slávy svet, I nebeskou klenbou skrytý velechrám, / kde večnou lampou bude samo - slnce!/ Ruš teda, bež, let... Boh ta sprevádzaj!“

P. O. Hviezdoslav bol aj politikom a poslancom Národného zhromaždenia. Bol presvedčený, že Slováci a Česi by mali zostat’ vždy spolu - v jednom štáte. Jeho československá orientácia bola sympatická Čechom do takej miery, že sa o neho zaujímali aj v čase, ked’ už zdravotne dost' trpel. A práve ku cti Čechov patrí aj to, že sa mu usilovali pomôct', a to liečením v Prahe a v Luhačoviciach, čo ostro kontrastovalo so slabým záujmom Slovákom o nášho - fyzicky a psychicky rapídne upadajúceho - básnického velikána v kritickom čase, teda v roku 1921, niekol'ko mesiacov pred jeho úmrtím 8. novembra 1921.

Vznik prvej ČSR nebol jednoduchý. Na tomto nelahkom procese participovali významné české a slovenské osobnosti. Podstatné bolo, že sa to podarilo, napriek velkým turbulenciám a kríženiu egoistických záujmov vtedajších mocností v čase prvej svetovej vojny. V spleti týchto záujmov pracovali obrovskou rýchlostou, no zároveň i velmi efektívne, aj tri vel'ké osobnosti, a to T. G. Masaryk, E. Beneš a vel'ký Slovák - generál Milan Rastislav Štefánik. Tento mladý, fyzicky nenápadný a chorlavý človek vykonal počas svojho krátkeho života klúčové historické činy, týkajúce sa nielen založenia a uznania prvej ČSR, ale aj čo sa týka záchrany životov tisícok slovenských a českých zajatcov v rôznych častiach sveta. Plasticitu a peripetie náročného života M. R. Štefánika stvárnil - v románe Prebijem sa! Štefánik. Muž železnej vôle (2018) - známy slovenský spisovatel’ Jozef Banáš. Autor na celej ploche románu „obnažuje“ obrovské množstvo historických dát, osôb i osobností, aby ako epik mohol kompozične velmi pútavo „naskicovat" zákulisie politických hier vtedajších mocností. Štefánik - chudobný chlapec z Košarísk - sa velmi často objavoval v kontexte mocenských, vojenských i politických špičiek vtedajšieho sveta. Jeho hodnost' francúzskeho generála, no hlavne charizma, skromnost' i ráznost', neústupnost', predvídavost', múdrost' - l’udská i vedecká, zároveň aj nevídaná schopnost' obetovat’ všetko pre svoj národ z neho robia výnimočného hrdinu slovenského národa. Štefánik precestoval pri plnení svojich vojenských i politických poverení obrovský kus sveta. Obdiv vyvolával najmä schopnostou sebažertvy pre svoj národ, a to napriek tomu, že cítil absolútne ohrozenie svojho života, a to z dôvodu velkých zdravotných problémov, riešenie ktorých odsúval, pretože služba národu bola pre neho absolútnou prioritou. Jeho predvídavost' a schopnost' „dejstvovat“ sú porovnatel’né iba so Štúrom, J. M. Hurbanom a slovenskými martýrmi z roku 1848 - Karolom Holubym, Viliamom Šulekom, či S. H. Vajanským, ktorý za svoje pronárodné cítenie musel sediet’ aj vo väzniciach. 
Popri politických reflexiách sa čitatel' v románe vel’a dozvie aj o Štefánikovej rodine; otcovi - evanjelickom kňazovi, o chudobe a d’alších tažkostiach v ich mnohopočetnej rodine i o jeho láske $\mathrm{k}$ talianskej markíze Giuliane Benzoniovej. Z literárneho aspektu pre nás zaujímavo a hlavne autenticky vyznieva Štefánikovo začlenenie do slovenského študentského spolku Detvan v Prahe, kde si Štefánik získal vel'ký obdiv a rešpekt. Navyše tu sa zoznámil s profesorom T. G. Masarykom, ktorý $\mathrm{v}$ tom čase začal pôsobit na Karlovej univerzite (po príchode z Viedenskej univerzity) a v Detvane mal prednášku. S Detvanom sa spája aj Štefánikove zoznámenie a priatel'stvo s literátom a neskôr aj významným slovenským lekárom a politikom Vavrom Šrobárom. Ich debaty odkrývali napätia medzi generáciou konzervatívnych Martinčanov na čele so S. H. Vajanským a hlasistami, ktorí boli pod vplyvom T. G. Masaryka. Zaujímavé sú aj Štefánikove stretnutia so slovenskými spisovatelmi - J. Jesenským a J. G. Tajovským, ktorí pôsobili v Rusku. Štefánik tam prišiel zachraňovat slovenských a českých ubiedených zajatcov a zaslúžil sa o to, že ich dostal - po obrovských peripetiách v Rusku a dlhom cestovaní - do bezpečia domova. Verboval českých a slovenských vojakov, aby vstúpili do československých légií, pretože chcel vytvorit základy budúcej armády v prvej ČSR. Nejasnosti okolo jeho smrti síce pretrvávajú, ale absolútne jasné je to, že išlo v danom čase o najväčšiu slovenskú osobnost', podielajúcu sa podstatným a hlavne nevídaným spôsobom na kreovaní histórie svetovej i slovenskej.

Zo staršej spisovatelskej generácie treba pripomenút aj mená ako M. Rázus, Š. Krčméry či R. U. Podtatranský, ktorí písali oslavné básne o prvej ČSR. Túto historickú udalost' najprv privítali, no neskôr sa nebáli (M. Rázus) ani kritizovat nespravodlivé riešenie tzv. slovenskej otázky (Hučková 2017, 320), prípadne múzicky objektívne reflektovat problémy vztahovosti slovenského a židovského živlu (Gallik 2017, 21 - 28).

Rok 1938, ako d’alší osmičkový rok, bol tragický a osudotvorný pre Čechov a Slovákov, a to z dôvodu podpísania Mníchovskej dohody 28. septembra 1938 tzv. politickými "elitami“ Európy, pretože tento fakt vyvolal retaz krokov, ktoré vyvrcholili vznikom tzv. slovenského štátu. Ten v marci 1939 uznalo aj fašistické Nemecko a podpísalo s ním Ochrannú zmluvu. Nečestnost’ Západu vo vztahu k ČSR sa prejavila v tom, že Západ kolaboroval s Nemeckom a pod tlakom Hitlera akomodoval všetky svoje rozhodnutia jeho vôli. Vtedy ČSR prišlo o tretinu svojho územia (odňatie okrajových častí územia ČSR Pol’skom, Mad’arskom a Nemeckom). Tzv. slovenský štát, o existencii ktorého vedú historici dodnes odborný i politický diskurz, vznikol 14. marca 1939 pod nátlakom hitlerovského Nemecka. Reakcie na tzv. slovenský štát sa dodnes rôznia, ale postoje prodemokraticky orientovaných občanov a spisovatelov boli prevažne negatívne. Treba pripomenút najmä meno slovenského prozaika Janka Jesenského, ktorý bol mimoriadne ostrým kritikom, ironikom a satirikom nedostatkov ludí, najmä v malomestskom prostredí. Ako básnik však reagoval už aj na predohru k vzniku tzv. slovenského štátu v roku 1938, čo si treba mimoriadne vážit', pretože taký postoj si v danej dobe vyžadoval vel'kú dávku osobnej odvahy. Prejavil ju tým, že spolu so spisovatelom J. G. Tajovským protestovali pred Slovenským snemom 14. marca 1939 proti vyhláseniu samostatnosti, spolu s dalšími, ktorí boli za zachovanie ČSR. Bolo to však už po vyjadrení súhlasu slovenských poslancov. Dôkazom vysokého morálneho kreditu a odvahy Janka Jesenského bolo uverejňovanie jeho kritických, satirických a ironických básní, ktoré neskôr vyšli vo výbere pod názvom Ostrým perom (1952). Už v roku 1938 uverejnil báseň Koncentrák, ktorá je napísaná vo vážnej tónine, pretože básnik si v plnej miere uvedomoval, čo sa dialo v Európe, aké hrôzy generovali nemeckí fašisti a národní socialisti, zároveň bol svedkom toho, aká vlna zla sa začala prejavovat aj u nás. Báseň Koncentrák je vyjadrením „genézy a inventúry“ pocitov básnika z nástupu patologickej doby a prisluhovačov fašizmu. Jesenský na malej textovej ploche kompozične velmi funkčne a múzicky mimoriadne účinne naznačil vlastnú pocitovú škálu, a to od štádia smiechu - pri pohlade na gardistický znak - cez zvážnenie, hnev, žial', plač, lahostajnost', 
dopracujúc sa až k stavu totálneho (bytostného) strachu, ked’ lyrický „hrdina“ dospel do štádia sebazachraňujúcej reakcie na fašistickú totalitu:

„Na stráž!“, revem a ruku mi zdvihol lak...

„Ty pokrytec si!... Čaká Ťa koncentrák!“

„Čaká Ťa koncentrák!“ - tak znie refrén básnika, ktorý je fixnou odpoved’ou mocných na akúkolvek reakciu ohrozeného človeka v čase nadvlády tyranov. Fixný refrén - podobne ako u E. A. Poea v jeho básnickej skladbe Havran - je odpovedou na rozmanité otázky, ktorými sa prezentuje fašistická moc: „Ty sa nám smeješ?", „Teba to mrzí?", „Ach, ty sa hneváš?", „Plačeš nad byvším?", „Nenadchýnaš sa?", „Ty čakáš spásu?" - „Spasí t’a koncentrák!" Všetky nastolené otázky majú jedinú odpoved', ktorá je dôkazom bezvýchodiskovosti a bezmocnosti človeka. Jesenského báseň bola anticipáciou toho, čo sa potom stalo klúčovým javom pre mnohých ludí istých rás a presvedčenia (holokaust, koncentráky, popravy, prenasledovanie, sliedenie, udavačstvo atd.). Tieto procesy vyvolávali fóbiu a obrovské rozčarovanie z dehumanizácie sveta. Jesenský to vyjadril v básni Melanchólia (december 1938). Melanchólia ako leitmotív básne a zároveň pomenovanie konštantného, nepríjemného stavu, ktorý zabíja v ludoch radost’ zo života. Ide opät o autoreferenčnú báseň, v ktorej autorský subjekt vyjadruje nespokojnost’ s politikou, filozofiou o ludských právach, autonómiou, rečami o krestanstve, agitáciou v divadle, v rozhlase i kine. Melanchólia ho neopúšta ani v krčme, ani na ulici, nenapravia to ani básnici a prozaici, preto hladá pokoj v kostole. Finále básne je repetíciou fixného fenoménu - melancholického stavu básnika, pretože aj vo dne aj v noci „tróni“ v jeho hlave. Aplikácia apoziopéz v básni poskytuje priestor na rozjímanie čitatela o situácii človeka uprostred hrôzostrašnej doby.

Odvahu básnika vyjadruje aj báseň Národná zástava z 5. 10. 1939. Zástava je v normálnych časoch symbolom národa a štátneho útvaru. Ironický paradox J. Jesenského však poukazuje na to, že slobodu a právo $\mathrm{v}$ danom čase oslavujú práve lupiči slobody a práva, zástava pozdvihuje len zločiny a zlosynov, kým hrdinov bije; zástava nečistí, ale zašpiní. Taká zástava nie je národu po vôli, pretože „ovieva oživených zradcov a šlahá čestné mŕtvoly“.

Záver básne J. Jesenského je postojovo jasný: „Národnú zástavu dnes zase / z rúk treba vyrvat nehodným, / tá patrí živej úcte k vlasti, / Poctivým, Chrabrým, Slobodným!" Z aspektu kompozičného je báseň osnovaná na účinnom kontraste a dvojakosti symbolu národnej zástavy s jeho efektívnou komparáciou v časoch slobody a tyranie. Kontrast čistoty zástavy a jej zašpinenia v časoch zrady národných záujmov jasne demonštruje postoj básnika k tyranom a chorej dobe.

Obdobie tzv. slovenského štátu sa stalo predmetom bytostného záujmu spisovatela Dominika Tatarku, ktorý vo svojom živote prešiel mnohými peripetiami. Napísal román, ktorému dal signifikantný názov Farská republika (1948). Chcel tým naznačit prepojenie cirkevnej a štátnej moci. Kedže román má sčasti aj autobiografický charakter, pôsobí na čitatelov autenticky. Topos románu predstavuje mesto Žilina, kde sa koncentrovali - podobne ako v celom štáte - patologické fenomény danej doby. Tie boli personifikované v postavách gardistov, ktorí využívali politickú situáciu na aplikáciu svojej moci a vlastné obohacovanie (arizátori židovských majetkov, udavači, prenasledovatelia Židov). V románe kreoval D. Tatarka naratív, v epicentre ktorého je postava Tomáša Menkina. Ten strávil vyše roka vo väzení, hoci bol nevinný. Autor využil v románe poetiku náhody, aby zobrazil stav ludí v štáte a atmosféru doby, v ktorej vládli zničujúce „diagnózy“: pokrytectvo, pasivita a mlčanie. Náhoda spočívala $\mathrm{v}$ tom, že komunista Lyčko zo strachu pred žandármi dal kufre s protištátnymi letákmi Tomášovi Menkinovi, hoci ten netušil, aký je ich obsah. Aj jeho poznanie Lyčka bolo „hmlistéc. Hoci ten ušiel a Tomáš bol neprávom väznený, neprezradil meno majitela kufrov. Jeho postväzenský život bol však poznačený touto osudovou náhodou a maximálne sa znížili jeho šance na pozitívne vnímanie dobovou spoločnostou (motív nezamestnanosti, 
spoločenskej ignorácie atd.). Zaujímavým bodom v kompozícii románu je stretnutie Tomášovej matky s prezidentom tzv. slovenského štátu Jozefom Tisom. Tá v snahe pomôct’ synovi mu - paradoxne - urobila zle, pretože v prúde reči ho označila za komunistu a neznaboha, čo si predtým mysleli aj vyšetrovatelia jeho prípadu s letákmi v kufroch. Tatarka vo svojom románe tematizoval stav dehumanizácie v klérofašistickom štáte a diferenciáciu ludí v spoločnosti podla postoja k oficiálnej (monštruóznej) moci. Prozaik plasticky zobrazil vládnuci teror a fóbiu ludí z bezcharakterných gardistov a ich nehumánnych skutkov. Tatarka sa v románe prezentoval kritickou optikou, pomenoval atribúty patologickej doby a ludí v nej. Vytvoril silné románové posolstvo tým, že upozornil na nečinnost’ a mlčanie ludí v zhubnom čase, ked' treba rázne konat’ a netolerovat' zlo, pretože inak to môže viest' k tragédii národa, paradoxne hrdiaceho sa svojím krestanstvom. Štát, ktorý vznikol pod vplyvom hitlerovského Nemecka a nebezpečnej situácie na Západe, velmi rýchlo naplnil charakteristiky klérofašizmu. Metamorfózy štátu priniesli tragické osudy najmä Židom, ktorí sa „vd’aka“ klérofašistom dostali do koncentračných táborov. Zozvieratštovanie ludí pod vplyvom fašistickej ideológie sa napokon prejavilo aj vo finále Tatarkovho príbehu, ked’ Tomáš Menkina dostal ako druhotriedny človek povolávací rozkaz na vojnu. Zmyslom Tatarkovho románu bolo poukázat na devastujúce praktiky a hlavne širokospektrálne následky zhubných procesov diktátorského režimu, čo predurčuje román na reaktualizované čítanie.

Zhubné procesy v Československu sa začali šírit aj neskôr, a to zásluhou Klementa Gottwalda, ktorý sa ako komunista dostal k moci na základe prevratu vo februári 1948 a na štyri decénia spolu so svojimi prisluhovačmi uzavreli vlastných občanov i štát do „kazajky“ neslobody, dogmatizmu a chorej ideológie. Na tému „Vítazného februára“ vzniklo mnoho oslavných básní, ktoré boli v čase totality forsírované, no po nežnej revolúcii sa mnohí ich tvorcovia za ne hanbili.

Rok 1968 predstavuje osobitnú kapitolu nielen v dejinách ČSSR, ale osobitne aj v dejinách Slovákov, pretože z toho istého miesta ako L. Štúr vzišiel aj líder „československej jari“ a obrodného procesu, tvorca koncepcie socializmu s ludskou tvárou, Alexander Dubček. To, že išlo o Slováka, ktorý mal nesmiernu odvahu v čase, ked’ vychádzal „mráz z Kremla“, si zaslúži osobitnú pozornost'. Hoci príchod „spriatelených armád“ 21. 8. 1968 a obsadenie nášho územia bolo tragédiou pre náš národ, zviditelnenie ČSSR vo svetovom politickom kontexte bolo absolútne neprehliadnutelné. Velmi účinné umelecké vyjadrenie tragickosti roku 1968 sa spája s menom spisovatelky Zlaty Solivajsovej. Ide o spisovatelku, ktorá s nesmiernou statočnostou niesla tažký kríž svojho života najmä preto, že napísala Abecedu pre obludy - rozprávku o intervencii sovietskych vojsk do Československa v roku 1968. Za to musela zaplatit krutú osobnú daň v podobe vyše 20-ročného mlčania a zaradenia jej diel na index. Z. Solivajsová vstúpila do slovenskej literatúry už v 50. rokoch. Ako senzitívna a asociatívna poetka sa knižne predstavila až v 60. rokoch, a to básnickými zbierkami Jablká plné hviezd (1962) a Vyhnanie z raja (1967). Až po vydaní týchto zbierok a andersenovsky ladenej rozprávke pre deti Svietnik s holubičkou (1968) vyšla Z. Solivajsovej v r. 1971, teda v čase začínajúcej sa normalizácie, zbierka rozprávok Klúč od každých dverí. Osud tejto knihy sa stal predzvestou analogického osudu jej tvorkyne. Po ideologických previerkach nemohlo vyjst’ mnoho kníh a niektoré z nich boli dokonca zošrotované. To bol aj prípad Z. Solivajsovej a jej súboru rozprávok Klúč od každých dverí, ktorý cenzori dekódovali ako estetickú provokáciu alegoricko-symbolickej proveniencie. Rozprávku Abeceda pre obludy, ktorá bola súčastou súboru rozprávok Klúč od každých dverí, označili za ideovo mimoriadne nebezpečnú. Práve v čase autorkinej tvorivej erupcie bol proti nej odštartovaný celý rad represií, ktoré vyústili do súdnych procesov a zhoršovania jej zdravotného stavu. Je však smutné, že aj druhé, t. j. ponežnorevolučné vydanie knižky Klúč od každých dverí v roku 1996 vo vydavatel'stve Tranoscius malo opät neetické finále. Riaditel' vydavatel'stva Karel Ilja Dvořák - paradoxne opät z ideologických dôvodov - nezaradil Abecedu pre obludy do uvedenej zbierky rozprávok. Zaradenie spomenutej rozprávky však 
evidentne nevyhovovalo politickému kontextu 90. rokov, takže z Abecedy pre obludy sa opätovne stalo politikum.

Z typologického hladiska patrí rozprávka Abeceda pre obludy medzi hierarchicky a hodnotovo najvyššie zaradené, teda k symbolickým rozprávkam. Prostredníctvom symbolov duba a tanku Z. Solivajsová konfrontuje dve kontradiktórne koncepcie života. Dub je podla Lexikónu symbolov (Biedermann 1992, 65) stromom so symbolickým významom, pre tvrdosṫ dreva symbolizuje vytrvalost', vernost' a neochvejnost'. V uvedenej rozprávke je dub ochrancom lesa, symbolom života, sily, vytrvalosti, radcovstva a komunikačnej kultúry, kým tank je symbolom krutosti, násilia, nepriatel'stva, smrti a komunikačnej negramotnosti. Spisovatelka modeluje dub ako symbol etického dobra, ktoré sa premieta do morálnej kvality činov a etickej vznešenosti duba. Dub je v rozprávke antropomorfizovanou a personifikovanou „postavou“, ktorá je schopná uskutočňovat koncept sebaprekračovania tým, že sa obetuje v mene budúcnosti za iných obyvatelov lesa. Autorka využíva paradox ako silný umelecký prostriedok na to, aby zvýraznila situáciu duba, ktorý „umiera“ po výstreloch z tanku, čo je síce tragické, no smrt’ duba prináša aj optimistickú dimenziu, pretože je zároveň triumfom dobra nad zlom. Dub totiž svojou váhou znefunkční tank, čím zachráni dalších obyvatelov lesa a zabezpečí im šance na prežitie: „Počúvaj, tank,' ozval sa dub, ked' vlna bolesti trocha opadla, ,neviem, z ktorej krajiny prichádzaš. Možno sú u vás všetci takí ako ty. Možno sa ani medzi sebou neviete dohovorit, ked'vaša reč je taká chudobná a taká strašná, ale pochop: my sme tu žili v pokoji, každý mal svoje miesto, svoju prácu, svoju reč a s výtržníkmi-vlkmi sme si vždy vedeli poradit'sami. Chceme tak žit i nad'alej. Vrát’sa, odkial'si prišiel, nepatríš medzi nás a nikdy ta za svojho neprijmeme. Svet je krásny, len pokým si všetci robíme dobre. Uprostred zla hynie každá krása...' ,Ta-ta-ta-ta-ta!' rapotala obluda a bolest' sa zahryzla ostrými zubami do duba. Vtedy sa dub strašne rozhneval. ,Odíd, obluda!' zahrmel z výšky na tank. ,Odíd, lebo tu pre teba niet miesta! Do nášho lesa nepatriš ani ty, ani tvoje meno, ani tvoja strašná abeceda. Je to abeceda pre obludy. Si tu votrelcom. Odíd’, už si narobil dost škody. Aj moja trpezlivost' má svoje hranice. Zahubím tá!“ (Solivajsová 1996, 30).

Polaritné koncepcie života sú z umeleckého hladiska zhmotnené do podoby dvoch symbolov, pričom dub sa stáva symbolom mravnosti. Z. Solivajsová v nebezpečných časoch vsadila na silné hodnotové relácie rozprávky a tomu prispôsobila aj autorskú stratégiu modelovania sveta, ktorá je mimoriadne esteticky pôsobivá aj napriek tomu, že dejová potencia príbehu je nízka. Sila zámeru textu pretransformovaná do kreatívnych výrazových prostriedkov vyvoláva u čitatela stav hlbokého estetického zážitku, ktorý vyplýva z eticko-estetickej vyváženosti. K zvýšeniu estetických kvalít jej rozprávky rozhodne prispel aj fakt, že lyrický naturel spisovatelky je nepopieratelný a z poézie si ho Z. Solivajsová v zmodifikovanej podobe preniesla aj do prózy. Navyše táto autorka bola „infikovaná“ estetizmom takých literárnych autorít, akými boli H. Ch. Andersen, A. de Saint-Exupéry a $\mathrm{O}$. Wilde, k čomu sa oficiálne priznala, podobne sa hlásila aj k vplyvom J. C. Hronského a ludových rozprávok. Preto sú jej rozprávky apoteózou klasickej trojjednoty dobra, krásy a pravdy. Obidve spomenuté rozprávkové knižky Z. Solivajsovej sú dôkazom toho, že spisovatel'ka považovala žáner rozprávky za oázu, v ktorej mohla nájsț to, po čom v reáli nesmierne túžila.

Na Slovensku - ešte v rámci ČSSR - bol však významným dátumom aj 25. marec 1988, a to z hladiska pokusu o pokojnú manifestáciu občanov (na Hviezdoslavovom námestí v Bratislave) za slobodu, dodržiavanie občianskych a náboženských práv. Iniciátormi Sviečkovej manifestácie alebo Bratislavského velkého piatku či Sviečkovej demonštrácie, ako bola označovaná táto historická udalost', boli predovšetkým veriaci ludia v spolupráci s tajnou cirkvou. Hoci tento významný počin slovenských občanov bol tvrdo potlačený komunistickým režimom, Sviečková demonštrácia jasne ukázala, tak v domácom, ako i v medzinárodnom kontexte, že sila totalitnej moci a nezmyselnost’ vládnucej ideológie sa dá oslabovat odvahou morálnych, antirežimisticky naladených ludí. Práve Slováci dokázali ako prví - už v rámci ČSSR - absolútnu nespokojnost', čo bolo de facto 
naštartovaním zmenotvorného procesu vedúceho k 17. novembru 1989. Predbiehanie Slovákov z hladiska ozdravných procesoch dokumentuje aj fakt, že odvážni bratislavskí študenti prejavili na Mierovom, dnes Hodžovom námestí už 16. novembra v Bratislave svoju vel'kú nespokojnost’ $\mathrm{s}$ daným stavom $\mathrm{v}$ štáte. Žiadali slobodu, demokraciu, zmeny v školstve a v dalších oblastiach života. To bolo druhé verejné vystúpenie Slovákov proti socialistickému zriadeniu, brzdiacemu normálny vývoj vo sfére občianskej, politickej, ekonomickej, kultúrnej atd’.

Na záver možno konštatovat', že v našich dejinách sme mali aj výnimočné osobnosti a odvážnych spisovatelov. Tieto osobnosti sa zviditelnili vd’aka svojej odvahe konat’ v čase istých historických výziev, no zároveň aj svojimi zásadovými postojmi k šíritelom zla. Preto si našu úctu zaslúži tak odvážna generácia slovenských romantikov na čele s L. Štúrom, ako aj spisovatelia z obdobia realizmu, moderny a d’alších vývinových fáz. Boli skutočnými hrdinami svojej doby, pretože svojou osobnou statočnostou a majstrovstvom pera oduševňovali národ a prebúdzali v ňom vedomie i svedomie. V našej histórii sú osmičkové roky dôkazom toho, že existuje silná prepojenost politiky a literatúry. Literatúra totiž v našich národných dejinách bud' múzickým alebo ideologickým spôsobom - ako slúžka politiky - „zrkadlila“ politické udalosti a procesy, a to bud” afirmatívne alebo odmietavo. A to by malo byt podstatné pri umeleckej tvorbe, pretože literatúra už v antike patrila medzi slobodné umenia.

\section{SUMMARY}

Based on the analysis and interpretation of selected artistic texts, the author summarizes the artistic contributions of significant Slovak writers and politicians who were either direct engineers of historical events in the Czech state and the Slovaks, as people and artists, at the same time responding to historically significant year of "Eights" (Štúr, Hviezdoslav, Jesenský, Tatarka, Solivajsová, Banáš and others). Reflected works have either a festive character, or they are a critical, ironic or satirical reaction to negative historical breaks. The selection of partially interpreted texts was made to show the change of historical processes, especially their positivity and progress, but also the decline and regression of the state and society at the time of the onset of dual totality. The artistic literature, in this case, appears not only as a specific "means of mirroring" history and politics in the transformation of time but, above all, is evidence of their close interconnection.

\section{LITERATÚRA}

Banáš, Jozef, 2018. Prebijem sa! Štefánik. Muž železnej vôle. Bratislava: IKAR.

Biedermann, Hans, 1992. Lexikón symbolov. Bratislava: Obzor.

Danilák, Michal, 1997. Ludovít Štúr a slovanský zjazd v Prahe roku 1848. In: Ludovít Štúr v súradniciach minulosti a prítomnosti. Zost. Imrich Sedlák. Martin: Matica slovenská.

Eco, Umberto, 2004. O literatuře. Praha: Argo.

Gallik, Ján, 2017. Nadčasovost’ Rázusovho Krčmárskeho krála. In: Opera slavica: slavistické rozhledy, 27/3, $21-28$.

Hučková, Dana, 2017. Slovenskost kontra internacionalizmus: Rázusove reflexie modernej slovenskej literatúry. In: Slovenská literatúra 64/4, 318 - 320.

Hviezdoslav, Országh, Pavol, 1931. Zobrané spisy básnické. In: Zväzok X. Básne príležitostné. Turčiansky Sv. Martin: Matica slovenská.

Jesenský, Janko, 1952. Ostrým perom. Bratislava: Smena.

Kepštová, Lubica, 1996. Klúč ku každému srdcu. In: Bibiana, 4/3 - 4, 25.

Solivajsová, Zlata, 1996. Abeceda pre obludy. In: Bibiana, 4/3 - 4, 27 - 30.

Tatarka, Dominik, 1963. Farská republika. Bratislava: Smena. 


\section{KONTAKT}

doc. PhDr. Marta Germušková, CSc.

Inštitút slovakistiky a mediálnych štúdií

Filozofická fakulta PU v Prešove

Ul. 17. novembra 15

08001 Prešov

Slovenská republika

marta.germuskova@unipo.sk 